\title{
Burning the Archive, Building the State? Politics, Paper, and US Power in Postwar Mexico
}

\begin{abstract}
This article explores how the Mexican state gathered, archived, and destroyed information. It focuses on the US-Mexico campaign against foot-and-mouth disease between 1947 and 1952, whose paper archive Mexican officials burned near the successful conclusion of the campaign. This article argues that several factors shaped the context for this documentary bonfire and made the 1940s a key point of inflection in Mexico's history of official information-gathering: the dominant party's system of elite power-sharing, the growth of a reading public, and the regime's drift rightward. At the same time, the nature of the foot-and-mouth disease campaign itself ensured that, despite its possible uses, the archive was particularly sensitive, providing evidence of the embarrassing gaps that began to yawn between the state's language of revolutionary nationalism and its political practise. Indeed, the bonfire represented the culmination of practises Mexican officials had already developed throughout the campaign to reconcile the demands of legibility and deniability, hemispheric integration and nationalism, political stability and state capacity. More broadly, the case illustrates the uneven effects of US assistance on the development of state capacity, the authoritarian but institutionally weak character of the early PRlísta state, and the role of archives in maintaining a coherent image of state sovereignty.
\end{abstract}

In August 1952, Oscar Flores Sánchez, Mexico's sub-secretary of agriculture, decided that hundreds of boxes of official records were not 'technically necessary' and ordered that they 
be burned. ${ }^{1}$ These boxes contained the Mexican archive of an unusual but revealing institution: the Joint US-Mexico Commission to Eradicate Foot-and-Mouth Disease (Comisión México-Americana por la Eradicación de la Fiebre Aftosa, or CMAEFA). Between 1947 and 1952, this commission counted, mapped, quarantined, sacrificed and vaccinated millions of head of livestock across a swathe of central Mexico, from the gulf coasts of Veracruz across the densely populated central plateau, to Guerrero and Oaxaca in the west. The campaign was, by any reasonable comparative measure, huge and expensive: it absorbed over half of the US economic aid budget to Latin America, and vaccinated more animals than any previous eradication campaign. ${ }^{2}$ It represented an audacious attempt to project state power into the countryside and an unprecedented exercise in everyday bilateral relations: the US government sent dollars, equipment (bulldozers, jeeps, tents), and hundreds of veterinarians, livestock inspectors, and cowhands, who- alongside Mexican counterparts, and thousands of Mexican troops- manned the campaign, criss-crossed the countryside in jeeps, on mule-back or in riverboats, encountered daunting problems and entrenched resistance, but eventually succeeded in eradicating the disease.

On the face of it, the fire is puzzling. Despite Flores' claims, the foot-and-mouth disease (FMD) campaign gathered much valuable epidemiological and sociological information useful to any state aiming to develop and dominate the countryside. The Mexican archives of other, smaller campaigns against screwworm or poultry disease did not suffer the same fate. The 1940s and 1950s were a time of rapid but starkly inequitable

\footnotetext{
${ }^{1}$ Miguel Vargas Solórzano, Sec. Agricultura y Ganaderia, to Javier Diez de Urdanivia, Jefe de la Oficina Federal de Hacienda, 30 November 1966, Archivo General de la Nación, Mexico (AGN), Secretaría de Agricultura y Gandería (SAG), Box 134, 'fiebre aftosa'.

2 United States Agency of International Development, US Overseas Loans and Grants Dataset (Greenbook), https://catalog.data.gov/dataset/us-overseas-loans-and-grantsgreenbook-usaid-1554 (accessed May 2018).
} 
economic growth- a so-called 'Mexican miracle' of industrialization and urbanization.

Conventional narratives also portray these years as the heyday of a powerful, monolithic and relatively bureaucratic party-state- a time when the political cockpit of the presidency controlled the country through the well-oiled machinery of a corporate party which, in 1946, adopted an appropriately oxymoronic moniker: the Party of the Institutional Revolution (Partido Revolucionario Institucional, or PRI). ${ }^{3}$ Moreover, many historians argue that globally, since the nineteenth century, massive outbreaks of animal disease epizootics- have stimulated the growth of state policing powers and 'cognitive capacity' - a government's capacity to gather and process information. ${ }^{4}$ The fire was also rather

\footnotetext{
${ }^{3}$ For critical overviews, see: Arthur Schmidt, 'Making it Real Compared to What? Reconceptualizing Mexican History Since 1940', in Gilbert Joseph, Anne Rubenstein, and Eric Zolov (eds.) Fragments of a Golden Age: The Politics of Culture in Mexico Since 1940 (Durham, 2001), 24; A. Knight, 'The Weight of the State in Modern Mexico', J. Dunkerley (ed.) Studies in the Formation of the Nation State in Latin America (London, 2002), 212-253. Despite growing critique, discussed below, this image of sweeping state and 'near imperial' presidential power lingers. R. M. Alexander, Sons of the Revolution: Miguel Alemán and His Generation (Albuquerque, 2016), 14.

${ }^{4}$ On 'cognitive capacity', see L. Whitehead, 'State Organization in Latin America Since 1930', in L. Bethell (ed.) Latin America: Economy and Society Since 1930 (Cambridge, 1998), 401. On epizootics and state-building see: K. Brown and D. Gilfoyle (eds.), Healing the Herds: Disease, Livestock Economies, and the Globalization of Veterinary Medicine (London, 2009); A. Olmsted and P. Rhode, Arresting Contagion: Science, Policy, and Conflicts Over Animal Disease Control (Cambridge, MA 2015); A. K. McVety, The Rinderpest Campaigns: A Virus, Its Vaccines, and Global Development in the Twentieth Century (Cambridge, 2018), 13-46; A. Woods, A Manufactured Plague: The History of Foot and Mouth Disease in Britain (London, 2004) 1-19; C. Strom, Making Catfish Bait Out of Government Boys: The Fight Against Cattle Ticks and the Transformation of the Yeoman South (Athens, Georgia, 2009); A. Ron, 'Farmers, Capitalism, and Government in the Late Nineteenth Century', The Journal of the Gilded Age and Progressive Era, 15, 3 (2015), 294-309. For the argument that foot-andmouth disease strengthened federal institutions in Mexico: M. Machado, An Industry in Crisis: Mexican-United State Cooperation in the Control of Foot-and-Mouth Disease (Berkeley, CA 1968); J. M. Cervantes Sánchez, A. M. Román Diaz, B. Velázquez Camacho, 'Una historia de vacunos y vacunas. Retrospectiva de la epizootia de Fiebre Aftosa a 65 años de distancia', Veterinaria, 12, 5 (2010); María Cecilia Zuleta, 'Y viene el cordón sanitario: Estado y defense agrícola y pecuaria en México en el siglo XX, de la Revolución a la segunda posguerra', paper presented at Primer Congreso Latinamericano de Historia Económica, Montevideo, December 2007.
} 
precipitate; the Mexican government continued to fight small outbreaks- with some US assistance- until eradication was finally confirmed in 1954. It did, however, coincide with the end of the administration of President Miguel Alemán (1946-52). Having implemented this extraordinary project of sanitary and social control, and gathered valuable information normally welcomed by the state, why burn it? What can this story tell us about the strengths and weaknesses of Mexico's mid-century PRlísta state?

The impulses to gather and destroy information run through Mexico's political history, although they are usually studied separately, and we have little understanding of how they interact over time. In the late nineteenth century, integration into global markets and growing state revenues supported (and demanded) more intensive mapping and census-taking, as they did across Latin America. ${ }^{5}$ After 1920, postrevolutionary nationbuilding and reform gave an impetus to information-gathering that was probably unusually strong in Latin America, while after 1940 the regime boosted and centralized its political intelligence services, amassing one of the largest secret police archives in Latin America. ${ }^{6}$ Mexican authorities have also routinely destroyed the information stored on the most readily available technology: paper. As Luis González y González noted, 'burning archives is an old Mexican tradition', and one to which local, regional and federal officials have contributed, alongside rioting townspeople and rebellious peasants. ${ }^{7}$ However, a handful

\footnotetext{
${ }^{5}$ R. Craib, Cartographic Mexico: A History of State Fixations and Fugitive Landscapes (Durham, NC 2004); M. A. Centeno, Blood and Debt: War and the Nation-State in Latin America (University Park, PA, 2002), 101-166. Experts and officials had already conjured a national territory and governable subjects, but struggled to flesh out these abstractions with statistical information. L. Meyer Celís, Entre el infierno de una realidad, y el cielo de un imaginario: estadística y comunidad científica en el México de la primera mitad del siglo XIX (Mexico City, 1999).

${ }^{6}$ Knight, 'The Weight', 216; Tanalís Padilla and Louise Walker, 'In the Archives: History and Politics', Journal of Iberian and Latin American Research, 19, 1 (2013), 1-10.

${ }^{7}$ L. González y González, Invitación a la microhistoria (Mexico City, 1997), 128.
} 
of studies aside, isolated anecdotes of this tradition are really all we have; even within this fragmentary picture, the Ministry of Agriculture's burning of the CMAEFA records stands out: the first documented example the author has found of a federal-level archive fire. James Scott's analysis of state-building and legibility is of limited use in connecting these competing impulses; it captures one of the objectives of some Mexican officials, some of the time, but tells us little about the relation of legibility to archiving; even during the PRI's heyday, Mexico's state was far from unified and civil society far from 'prostrate'. ${ }^{8}$

This article argues that several factors combined to create Flores's bonfire, and made the 1940s a key point of inflection in Mexico's history of official informationgathering. The PRI's tacit system of elite power-sharing, the growth of a reading public, and the regime's drift rightward all shaped the context for Flores' decision. At the same time, the nature of the FMD campaign itself ensured that, despite its potential uses, the archive was particularly sensitive, providing evidence of the embarrassing gaps that began to yawn between the state's language of revolutionary nationalism and its political practise. Indeed, the bonfire represented the culmination of practises Mexican officials had already developed throughout the campaign to reconcile the demands of legibility and deniability, hemispheric integration and nationalism, political stability and state capacity.

This story contributes to the historiography of US-Mexico relations and to recent efforts to re-examine the PRlísta state. Scholars have long recognized that the Second World

More examples of archival destruction are discussed below.

$8 \mathrm{~J}$. Scott, Seeing Like a State: How Certain Schemes to Improve the Human Condition Have Failed (New Haven, 1998), 5. For useful critiques of the applicability of Scott's ideas to modern Mexico: P. Piccato, 'Comment: How to Build a Perspective on the Recent Past', Journal of Iberian and Latin American Research, 19, 1 (2013), 99-110; A. Mathews, 'State Making, Knowledge, Ignorance: Translation and Concealment in Mexican Forestry Institutions', American Anthropologist, 110, 4 (2008), 484-494. 
War and the early Cold War propelled the political, economic and social integration of Mexico with the United States, and fostered a broad ideological consensus among US and Mexican officials about the need for capitalist development and industrialization. ${ }^{9}$ Recent studies have explored how this process produced new tensions and problems: Mexican officials worked extensively with US agencies to legitimize a new phase in bilateral relations while concealing the depth and intricacy of 'everyday forms of transnational collaboration'; they also strained to secure policy concessions and deflect unwanted US intrusions. ${ }^{10}$ The case of the CMAEFA bolsters these findings, and deepens our understanding of how hemispheric integration shaped the politics of information and archives. US assistance and advice may have helped build the capacity of Mexico's intelligence services, but its impact on other state agencies was uneven and subject to competing domestic political dynamics. ${ }^{11}$ The image of those dynamics that emerges from this story is broadly consistent with new research depicting the PRlísta state as authoritarian, pro-capital but institutionally weakwhat Paul Gillingham and Benjamin Smith dub a 'soft' authoritarian regime, or dictablanda.

\footnotetext{
9 B. Torres Ramírez, México en la segunda guerra mundial: historia de la Revolución Mexicana, periodo 1940-1952 (Mexico City, 1979); S. Niblo, War, Diplomacy, and Development: The United States and Mexico, 1938-1954 (Wilmington, 1995); F. Schuler, Mexico between Hitler and Roosevelt: Mexican Foreign Relations in the Age of Lázaro Cárdenas, 1934-1940 (Albuquerque, 1999); 173-198.

${ }^{10}$ S. Fein, 'Everyday Forms of Transnational Collaboration: US Film Propaganda in Cold War Mexico', in G. Joseph, C. C. Legrande, and R. Salvatore (eds.), Close Encounters of Empire: Writing the Cultural History of US-Latin American Relations (Durham, 1999). See also, S. Fein, 'Myths of Cultural Imperialism and Nationalism in Golden Age Mexican Cinema', in G. Joseph, A. Rubenstein, E. Zolov (eds.), Fragments of a Golden Age, 159-198; H. Jones, The War Has Brought Peace to Mexico: World War Il and the Consolidation of the PostRevolutionary State (Albuquerque, 2014); R. Alexander, Sons of the Revolution, 123-14. On Mexican official efforts to maintain a nationalist image and alliance with the United States after the Cuban Revolution, see R. Keller, Mexico's Cold War: Cuba, the United States, and the Legacy of the Mexican Revolution (Cambridge, 2015).
}

${ }^{11}$ A. W. Navarro, Political Intelligence and the Creation of Modern Mexico, 1938-1954 (University Park, PA, 2010). 
${ }^{12}$ The dictablanda concept has made some historians uneasy; Jaime Pensado and Enrique

Ochoa argue that it underplays the state's reliance on far-from-soft repression, while its emphasis on the state's contradictions and 'complexity' distracts from the blunt fact of systematic, and increasingly 'modernized' state domination. ${ }^{13}$ Yet, the story of the FMD campaign (and its archive) supports the substance of the dictablanda idea in two key ways. First, the campaign ill-fits the mould of a unified project of modernization imposed by force; it only succeeded because the government combined bouts of heavy-handed repression and predatory corruption with various formal and informal mediations and concessions. Second, it reminds us that, despite gains in political intelligence, overall the PRlísta state tended to opt for longevity over institutional penetration or, in Mann's terms, 'infrastructural power'.

${ }^{14}$ As a political creature, the PRlísta state had remarkable 'stamina', but limited fiscal, military, or bureaucratic 'muscle'. ${ }^{15}$ It also had very patchy administrative vision. Still, like a

12 P. Gillingham and B. T. Smith, Dictablanda: Politics, Work, and Culture in Mexico, 19381968 (Durham, 2014).

13J. Pensado and E. Ochoa, 'Introduction', in J. Pensado and E. Ochoa (ed.), México Beyond 1968: Revolutionaries, Radicals, and Repression During the Global Sixties and Subversive Seventies (Tucson, 2018) 3-18, 8, 14 n21.

${ }^{14}$ M. Mann, 'The Autonomous Power of the State: Its Origins, Mechanisms, and Results', European Journal of Sociology, 25, 2 (1984), 185-213. Hence, we find the same trade-off between political stability and 'infrastructural power' within the Ministry of Agriculture that scholars have identified for taxation and military recruitment. B . Smith, 'Building a State on the Cheap: Taxation, Social Movements, and Politics', in Gillingham and Smith (eds.) Dictablanda, 255-76; T. Rath, " "Que el cielo un soldado en cada hijo te dio...": Conscription, Recalcitrance, and Resistance in Mexico in the 1940s', Journal of Latin American Studies, 37, 1 (2005), 507-531. For a call by political scientists for further study of the historical relationship between state autonomy and infrastructural power, see H. Soifer, M. vom Hau, 'Unpacking the Strength of the State: The Utility of State Infrastructural Power', Studies in Comparative International Development, 43, 3-4 (2008), 219-230, 224.

${ }^{15}$ Knight, 'The Weight', 238. 
political 'pufferfish', it developed good camouflaging instincts; officials became adept at concealing limitations with an inflated image of size and power. ${ }^{16}$

It is difficult for historians to tell the story of institutional repositories that go up in smoke, but this case offers a methodological advantage: a parallel archive exists. ${ }^{17}$ The US 'section' of the commission also kept extensive records, deposited with the Bureau of Animal Industry in Washington DC at the campaign's conclusion. US records certainly have their blind spots and biases but, combined with stray documents and maps which lodged in other Mexican archives, miscellaneous private collections, and participant memoirs, we can reconstruct a general picture of the kind of information gathered by the Mexican 'section' of the CMAEFA, and the probable value and danger of keeping it. To show how the commission worked in practise, the following account reconstructs bureaucratic practises and disputes in the commission in some detail; formal operational agreements were hastily drawn-up and vague, and much of the work of sharing and exercising sovereignty in the commission was done informally, in the everyday conflicts over policy, money, machinery, authority, and information officials confronted. ${ }^{18}$ First, this article surveys the commission's

\footnotetext{
${ }^{16}$ P. Gillingham, 'Maximino's Bulls: Popular Protest after the Mexican Revolution', Past and Present 206 (2010): 176-211, 181.

${ }^{17}$ For a rare and insightful Latin American collection of cases, see Aguirre and Villa-Flores (eds.), From the Ashes. Another valuable parallel archive- the result of transnational scholarly rather than international collaboration- is the Mexican Intelligence Digital Archive (MIDAS), built to make re-restricted documents from intelligence agencies available to the public. http://www.crl.edu/midas (accessed June 20, 2019).

18 This approach builds on historical and ethnographic studies which have aimed to uncover social dynamics obscured by monolithic accounts of the state or starkly dichotomous portrayals of US-Latin American relations. T. Blom Hansen, F. Stepputat, States of Imagination: Ethnographic Explorations of the Postcolonial State (Durham, NC 2001); A. Sharma, A. Gupta (eds.) The Anthropology of the State: A Reader (Oxford, 2006); A. Mathews, 'State Making'; G. M. Joseph, C. C. Legrand, R. Salvatore (eds.) Close Encounters of Empire: Writing the Cultural History of US-Latin American Relations (Durham, NC 1998); T. Schwegler, 'Navigating the Illegible State: Governmentality and Political Process,' in Governing Cultures: Anthropological Perspectives on Political Power, Labor, and
} 
campaign and its gathering of information. The article then discusses the reasons why Mexican officials likely considered this information- or at least some of it- politically damaging, and why this overrode the potential benefits of keeping it. It then illustrates these arguments with the story of how officials managed a major public scandal after a commission plane crashed into Citlaltépetl, also known as the Pico de Orizaba, Mexico's highest peak.

Mexico's FMD crisis reflected the growing economic and political integration of the Western Hemisphere, and particularly new connections between the United States and Mexico. After Mexican veterinarians found cases of FMD in the state of Veracruz in November 1946, the origins of the outbreak were hotly debated; the government eventually blamed the illegal import of some zebu breeding bulls from Brazil- where FMD had been enzootic since the early twentieth century- by a murky consortium of Mexican businessmen and politicians along with a faction of US ranching interests. ${ }^{19}$ The campaign itself was modelled on several other joint commissions created during the Second World War to coordinate military defence, trade, US loans, and the program of Mexican guest workers known as braceros; indeed, several CMAEFA personnel had served in these entities. (The campaign's equipment- most of it sourced from post-war US army surplus- made the connection to the wartime mobilization of resources still more obvious.) However, while political elites in both countries increasingly accepted the principle and necessity of institutionalized cooperation on a host of issues, the practical details left ample room for

Government, Kendra Coulter and William R. Schumann eds. (London, 2012), 21-46; P. Sutter, 'Nature's Agents or Agents of Empire?: Entomological Workers and the Environmental Change during the Construction of the Panama Canal', Isis, 98, 4 (2007), 724-754. ${ }^{19}$ M. Machado, Aftosa: A Historical Survey of Foot-and-Mouth Disease and Inter-American Relations (Albany, 1969), 38-9. 
tensions and conflict. Growing integration also posed symbolic challenges for the Mexican government, and propagandists and film-makers worked to reconcile Mexico's discourse of revolutionary nationalism (and evidence of continued US imperialism and abuses) with the deepening ties to the United States. ${ }^{20}$ The FMD campaign- urgent, almost entirely unforeseen, unprecedented in scale- only aggravated these difficulties. ${ }^{21}$

The campaign went through several phases. The US and Mexican governments had long considered FMD a grave threat to their livestock industries; it infected cloven-hoofed animals, and cattle, pigs, and goats typically developed painful ulcers and blisters, and lost weight; while most animals recovered, mortality rates among younger animals could be over 50\%; in the 1940s, US experts estimated that FMD reduced overall meat and dairy production by $25 \%$. The US government also increasingly viewed agricultural concerns through a geostrategic lens; during the Second World War, the US military had begun to view FMD disease as an important biological threat to food supplies and national security; it had worried about German use of FMD in germ warfare, and then became anxious about Soviet plans. ${ }^{22}$ At the same time, the campaign offered the chance for both governments to project an image of progressive, anti-communist hemispheric cooperation. However, as elsewhere, agreement on policies of FMD control and eradication was elusive. The US government initially favoured the most extreme available method-mass slaughter and

\footnotetext{
${ }^{20}$ Fein, 'Everyday Forms'; D. Cohen, Braceros: Migrant Citizens and Transnational Subjects in the Postwar United States and Mexico (Chapel Hill, 2011), 204-5.

${ }^{21}$ In 1924-6, both governments cooperated on a much smaller and little-known eradication campaign in the state of Tabasco. 'La fiebre aftosa en Tabasco', Medicina Veterinaria, 1, 2 (1926) 1-2.

${ }^{22}$ T. Rath, 'A Tale of Four Laboratories: Politics, Science, and Animal Disease in Cold War Latin America', in Andra Chastain and Timothy Lorek (eds.), Itineraries of Expertise: Science, Technology, and the Environment in Latin America's Long Cold War (forthcoming, Pittsburgh).
} 
burial of livestock- and brought enormous diplomatic pressure on Mexico to adopt it. The FMD virus was highly contagious; it spread through livestock shipments, but also through dirt and dust gathered on clothes, goods, and vehicles; the US even threatened to halt all trade and migration across the US-Mexico border unless Mexico adopt adequate measures. By the end of 1947, however, popular unrest, economic disruption and low-level diplomatic pressure from Mexico had forced a change, and the campaign shifted to a more palatable blend of vaccination, isolated slaughter, and repeated waves of inspection. ${ }^{23}$

Each phase demanded accurate information, both quantitative and qualitative, about livestock and their owners, their movements, and more generally about public attitudes to state intervention. Earlier censuses and maps proved unreliable, and people's propensity to hide animals, the opaque nature of peasant practises of land-holding, informal grazing arrangements, and the shifting, ad hoc nature of the 'roads' along which livestock travelled made this information hard to obtain. ${ }^{24}$ Despite some improvements by the 1930 s, authorities' view of the contours of rural property and agriculture remained heavily clouded. ${ }^{25}$ Much of what the US anthropologist Ralph Beals observed in 1940-41 in the Tarascan village of Cherán, Michoacán applied to peasants and smallholders across the

\footnotetext{
${ }^{23}$ Several valuable regional studies of protest now exist, although we lack a systematic and comparative account: Ana Cecelia Figueroa Velázquez, El tiro de gracia al campo queretano (Querétaro, 2011); Tanalís Padilla, Rural Resistance in the Land of Zapata: The Jaramillista Movement and the Myth of the Pax PRlísta, 1940-1962 (Durham, 2008), 143-5; José Carmen Soto Correa, El rifle sanitario, la fiebre aftosa y la rebelión campesina: guerra fría, guerra caliente (México, 2009). For a useful overview of the campaign that also emphasizes peasant resistance, see John Ledbetter. 'Fighting Foot-and-Mouth Disease in Mexico: Popular Protest Against Diplomatic Decisions', Southwest Historical Quarterly 104: 3 (2001): 386-415.

${ }^{24}$ M. de la Peña, Guerrero Económico (n.p., 1949), 22. On the variability and difficulty of identifying rural 'roads' compared to railways, see Knight, 'Weight', 233, n.100.

${ }^{25}$ M. Ervin, 'Statistics, Maps and Legibility: Negotiating Nationalism in Post-Revolutionary Mexico', The Americas, 66, 2 (2009), 155-179.
} 
central plateau: 'Ownership of cattle is widespread...but accurate knowledge of the extent of ownership is impossible because of the tendency to conceal wealth. As most cattle are kept at pasture, usually in the mountains, house censuses are of no value'. ${ }^{26}$ The costs and productivity of pig and chicken-raising were similarly opaque, either because (as Beals believed) peasants never quantified such things or (as seems more likely) they feigned ignorance. ${ }^{27}$

In response, commission employees- largely drawn from the US and Mexican Ministries of Agriculture- collected their own information about livestock, sketched crude maps, corrected outdated place-names and livestock routes, gathered records on cattle breeds -often confronting a cacophony of local categories and standards-, and counted and documented the livestock appraised, slaughtered, and vaccinated in each town and village. ${ }^{28}$ Some states, like Guanajuato, had fairly reliable maps, although the commission struggled to secure enough copies. Guerrero, by contrast, contained wholly unmapped sections, had few paved roads, and was notoriously hostile; in response, the commission hired Mexican 'information men' to produce their own reports on local conditions, translations of which were forwarded to the US section. These reports reproduced many

\footnotetext{
${ }^{26}$ R. L. Beals, Cherán: A Sierra Tarascan Village (Washington DC, 1946), 29.

27 'It is virtually impossible to secure useful data on labor costs or profits in relation to animals...probably no-one in Cherán knows how much grain he feeds chickens, or how many eggs a year he gets...the situation about pigs is little better'. Ibid., 68.

${ }^{28}$ For some sketches and local censuses which avoided destruction, see Comisión MexicanaAmericana para la eradicación de la fiebre aftosa: Distrito de Huajuapam. Sector de Chalcatongo (n.p., n.d.), microfilm at Bancroft Library, University of California, Berkeley. On the difficulty of classifying breeds, see various correspondence, Mulhern, Oaxaca City, to Mexico City, July-August 1947, National Archives and Records Administration, Record Group 17, Bureau of Animal Industry, Commission for the Eradication of Foot-and-Mouth Disease (CEFMD), Operations, Box 29, Oaxaca.
} 
long-standing official ideas and stereotypes about Guerrero's geography and 'wild' society. ${ }^{29}$ One 'information man', Federico Sánchez, divided the state into four conventional geographic areas (the costa grande, costa chica, the tierra fría of the central highlands, and tierra caliente; each area offered distinctive cultural and ethnic obstacles to state action, but particularly the coastline - filled with men accustomed to laziness and criminality- and the tierra caliente: 'the most dangerous area', infested with cattle-rustling, banditry, and blood feuds. Still, amid the geographic cliché and ethnic stereotypes, Sánchez also gathered new information about attitudes to vaccination, lists of more or less cooperative towns, and key powerbrokers and institutions in the state. ${ }^{30}$

Formal information gathering had limits. This was a rushed operation, and in many places the commission had to rely on local guides. One such 'Indian scout' sent into the Huasteca to find evidence of unmarked livestock trails relayed typically dispiriting news to his supervisor: 'Well, he said people were moving in all directions and that the trails go in all directions, north, east, south, and west...Indians move all the time, anywhere'. ${ }^{31}$ Guides were often recruited by carefully selected bilingual cultural mediators on the commission staff: men like John López, a Mexican-American former priest and labor organizer, who had lived on both sides of the border. During 1947 López earned a reputation as a particularly skilled mediator, possessed of an unmatched ability to secure informants. Such skills also

\footnotetext{
${ }^{29}$ R. López, 'Visiones cartográficas de un Guerrero Bronco, 1791-1940', in B. Canabal et al. (eds.) Moviendo Montañas: Transformando la Geografía del Poder en el Sur de México (Chilpancingo, 2003). Some municipalities in Guerrero really did boast very high homicide rates. P. Gillingham, 'Who Killed Crispín Aguilar? Violence and Order in the PostRevolutionary Countryside', in W. Pansters, Violence, Insecurity, and the State in Mexico (Stanford, CA 2012), 91-111.

${ }^{30}$ Lic. Federico Sánchez, 'Information Man Supervisor', Guerrero, c. September 1949, CEFMD, General Subject Files, Box 10, c-11 Guerrero.

${ }^{31}$ Dr Connolly, Ciudad Valles, to Mr Reid, Mexico City, Radio log, 19 April 1948, CEFMD, Operations, Box 29, Radio Logs.
} 
had their limits; in early 1948 López was ambushed by two men while rowing up the Coatzacoalcos river; he was shot dead. ${ }^{32}$

Many Mexican officials and scientists resented the campaign's early reliance on slaughter and the disruption it caused, but it did allow them to reshape Mexican state institutions and, in some ways, boost cognitive capacity. Over time, the commission's improved knowledge of topography, ranching practises and livestock movements allowed it to create far more effective and enforceable quarantine lines. In 1948-9, commission officials engaged in repeated waves of inspections and vaccinations created a more accurate census of livestock. ${ }^{33}$ By the early 1950s, with US assistance, Mexico had installed an extensive radio system linking the Ministry of Agriculture's various stations across the countryside, boosted veterinary training and numbers, organized a system of lay disease inspection teams, and built an up-to-date laboratory outside Mexico City to test disease samples sent in from the distant campo. ${ }^{34}$ Together these formed a new veterinary infrastructure, and a somewhat weightier state presence in the countryside; combined with growing air transport, they allowed for 'a hitherto unprecedented degree of spatial precision and quick reaction for health measures in Mexico'. ${ }^{35}$ Still, some gains were temporary. In the 1950s and 1960s, the Secretariat of Agriculture's annual livestock figures

\footnotetext{
32 US officials privately suspected the assailants were gunmen paid by local ranchers. Various correspondence, CEFMD, Reports, Box 2, 'John Lopez'. On local guides and state blindness, see Scott, Seeing, 54.

${ }^{33} \mathrm{G}$. Wilkins Sigsworth, 'The Mexican Epizootic of Foot-and-Mouth Disease: A Study in the Spread, Eradication, and Impact of Infectious Livestock Disease, and Associated Modernization in the Livestock Sector' (PhD dissertation, University of Illinois at UrbanaChampaign, 1975), 203-4, 241; Connolly, Ciudad Valles, to Anderson, Mexico City, 17 March 1948, CEFMD, Operations, Box 29, Radio Logs.

${ }^{34}$ Cervantes Sanchez, et al. 'Una historia'; Rath, 'Tale'. On improving radio connections, see J. H. Eakin, Borderland Slaughter, A Love Story: Chronicle of the US-Mexico Campaign to Eradicate the Hoof-and-Mouth Virus (Buenos Aires, 2002), 94.

${ }^{35}$ Sigsworth, 'Mexican', 280.
} 
were still notoriously unreliable; local officials regularly inflated the overall numbers to impress superiors, but underestimated figures on productivity and slaughter due to tax evasion. (Some figures verged on the magically real, as when the ass population of San Luis Potosí reportedly increased from 15 to 97,638 in five years.) ${ }^{36}$

By offering some opportunities for building infrastructural power, the bilateral commission was indicative of a larger process unfolding in Mexico- indeed across much of Latin America- in the 1940s and 1950s. Closer integration with the United States during the Second World War provided opportunities to develop new techniques of information gathering and statecraft. Besides US support for Mexico's political intelligence services, the US and Mexican militaries collaborated on a project of aerial mapping of strategic coastal and border areas; by the 1950s, US support for military mapping continued through the Interamerican Geodesic Institute, based in Kansas. The Rockefeller Foundation- more closely tied to the US State Department and the Washington-based Institute of Interamerican Affairs than ever before- played a similar role in agricultural research and public health, supporting Mexican efforts to amass more and better information about its population, soils, and seeds. The Federal Bureau of Narcotics also deepened its partnership with the office of the Mexican Attorney General, although it generally remained restricted to border areas before the 1960s. In 1947 US officials were well aware that the budget and geographical reach of the CMAEFA far outstripped nascent bilateral counter-narcotics initiatives. ${ }^{37}$

\footnotetext{
${ }^{36}$ P. L. Yates, Mexico's Agricultural Dilemma (Tucson, 1981), 275.

${ }^{37}$ Navarro, Political Intelligence; Boletín No.2 de la Comisión Cartográfica Militar (Mexico City, 1953); J. Cotter, 'The Rockefeller Foundation's Mexican Agricultural Project: A CrossCultural Encounter', in M. Cueto (ed.) Missionaries of Science: The Rockefeller Foundation in Latin America (Bloomington, IN 1994), 97-125; S. Baker Opperman, 'Using Public Health Crossings to Create Community-Based Heathcare in Mexico: The Case of Two Health Centres
} 
Despite a host of problems, by the early 1950s the CMAEFA had gathered a

formidable body of data that was far from technically worthless. Much of the information gathered by the campaign - everyday operational correspondence and radio logs, detailed records of sanitary inspections, slaughter, indemnities, and vaccination drives by town and village- would, other things being equal, have afforded various potential uses. Indeed, this was the kind of information usually welcomed by the state for the purposes of tax collection, social and sanitary control, and political management. Prior to burning the archive the Ministry of Agriculture retained some synoptic information: a chronological record of initial infection by municipality, and aggregate statistics on livestock slaughtered by federal state. However, these aggregate figures were too broad-brush for many uses. Years later, Grant Wilkins Sigsworth, a visiting geography researcher, sifted through the meagre remaining records and complained that the lack of detailed local records hindered a precise analysis of the epidemiology of the disease. ${ }^{38}$ Similarly, records would have contained a wealth of valuable sociological information: the livestock owners affected, their backgrounds and scale of operations, not to mention detailed records of more or less cooperative regions, villages, and subnational authorities. To a central state interested in

in Xochimilco', Bulletin of Latin American Research 38, 1 (2019): 35-49; C. A. Pérez Ricart, 'Las agencias antinarcóticos de los Estados Unidos y la construcción transnacional de la guerra contra las drogas en México (1938-1978)' (PhD dissertation, Freie Universität Berlin, 2016); Delagrave to Commissioner of Customs, Report on 1947 Opium Poppy Destruction Campaign, 19 August 1947, NARA, Record Group 170, Box 23. The bracero guest-worker program triggered some modest Mexican efforts to register male workers and regulate labor markets, although they were often undermined by domestic corruption and US agribusiness support for illegal migration. D. Fitzgerald, A Nation of Emigrants: How Mexico Manages Its Migration (Berkeley, CA 2009), 48-55.

38 The commission only retained records of infection in municipalities by monthly intervals, rather than more frequent and detailed tallies of infected populations; nor did they record instances of reinfection. Sigsworth, 'Mexican,' 81. 
boosting productivity and preventing disease, in penetrating local societies in order to soften them up for further domination, presumably all this would have been useful information.

Why then burn the archive? Central to any explanation is the PRI's federal powersharing agreement, whereby different patronage networks- dubbed camarillas- combined to back a presidential candidate, enjoyed the authority and spoils of public office with sweeping impunity, before handing power to a new coalition of insiders at the end of the presidential sexenio (six-year term). It would be misleading to describe this tacit agreement in too rigid terms. Between 1940 and 1952, the rules of the political game were still being formed and tested: the 1940 and 1952 presidential elections were hard-fought; women got the vote in local elections in 1946 and in 1946-8 the PRI briefly loosened central control of party primaries; in 1948 disgruntled military factions plotted to topple President Alemán; reportedly Alemán himself contemplated presidential re-election for a short time; camarillas were themselves loosely organized and shifting groups, rather than mutually exclusive clubs. ${ }^{39}$ However, numerous anecdotes indicate that this arrangement, and Mexico's lack of a career civil service, imposed a fairly predictable tempo on archival purges, as federal administrators covered their tracks before departing office or moving elsewhere. With each new sexenio, the heads of federal institutions purged their records before handing them

\footnotetext{
39 Navarro, Political Intelligence, 13-78, 198-255; P. Gillingham, '"We Don't Have Arms, But We Do Have Balls": Fraud, Violence, and Popular Agency in Elections', in P. Gillingham and B. Smith (eds.) Dictablanda, 147-79; B. Fallaw, Cárdenas Compromised: The Failure of Reform in Postrevolutionary Yucatán (Durham, 2001), 8. Women's enfranchisement reflected industrialization and a growing female workforce, the emergence of a welfare state, and advocates' move from a discourse of equality to maternalism, but scholarship on the impact of this change is scant. S. Buck, 'The Meaning of the Women's Vote in Mexico', in S. Mitchell and P. Schell (eds.), The Women's Revolution in Mexico, 1910-1953 (Basingstoke, 2007), 73-83.
} 
over to the national archive. ${ }^{40}$ Fires at federal archives punctuated 1982, a year of presidential turnover and severe economic and political crises: an accidental fire gutted Mexico's largest cinema archive; a highly suspicious fire destroyed the archive of the national oil company, coinciding with a major corruption scandal; Arturo 'El Negro' Durazo, the notoriously corrupt head of the Federal District police, also burned an 'enormous quantity' of police 'files, documents, photographs, microfilms, and films' before leaving office. ${ }^{41}$ Similar practises endured long into the supposedly more technocratic 1990s, when official transfers at the Mexican Institute of Social Security were heralded by 'an empty office or...a secretary frantically shredding files.' ${ }^{42}$ Federal practise may have imitated provincial precedent; in the 1920s census-takers complained that outgoing presidentes municipales destroyed their archives as a matter of course, usually by burning them; in the 1930s and 1940s, state governors in Puebla, Morelos, and Yucatán did the same, or sold their archives for paper mulch. ${ }^{43}$

${ }^{40}$ Francisco Valdés Ugalde, 'La corrupción y las transformaciones de la burguesía en México, 1940-1994', in C. Lomnitz (ed.), Vicios públicos, virtudes privadas: la corrupción en México, 195-237, 206; A. Paxman, personal communication, December 2017

$41 \mathrm{~J}$. Villa-Flores, 'Plotting a Fire: The Burning of Mexico's Cineteca Nacional and the Idea of a Self-Destructing Archive', in C. Aguirre and J. Villa-Flores (eds) From the Ashes of History: Loss and Recovery of Archives and Libraries in Modern Latin America (Chapel Hill, NC 2015), 197-226; P. Gillingham, personal communication, November 2017; R. Rodriguez Castañeda, 'Durazo destruyó archivos policiales para limpiarse y entrar al actual gobierno', Proceso, 21 July 1984.

42 T. Schwegler, 'Navigating the Illegible State', 30.

${ }^{43}$ M. A. Ervin, 'The 1930 Agrarian Census in Mexico: Agronomists, Middle Politics, and the Negotiation of Data Collection', Hispanic American Historical Review, 87, 3 (2007), 537-570, 558; A. Paxman, Jenkins of Mexico: How a Southern Farm Boy Became a Mexican Magnate (New York, 2017), 11-12; B. Fallaw, A. Paxman, B. Smith, personal communication, November 2017. For examples of revolutionary generals doctoring or burning personal archives, see: T. Rath, Myths of Demilitarization in Postrevolutionary Mexico, 1920-1960 (Chapel Hill, NC 2013), 145; J. Womack, Zapata and the Mexican Revolution (New York, 1968), 417. In 1943, a frustrated US military attaché observed of one prominent political general: 'For some unexplained reason there are two sets of records on General (Ramón) Rodriguez Familiar in the War Department files. These records differ 
Such practises would have made little sense without the existence of an increasingly literate public, eager to parse official documents leaked to newspapers. By the end of the 1930s, the postrevolutionary state had obtained unprecedented control of Mexico's public sphere. ${ }^{44}$ Still, as literacy expanded, the press - even the much maligned national pressretained a political role. While avoiding direct criticism of the president, it was still occasionally capable of concerted action that imposed limits on what was politically possible, and forced the PRI to refashion how Mexico was governed. ${ }^{45}$ Although the party and state were increasingly intertwined, PRlísmo remained a broad ideological and political church, made up of competing regional camarillas and sectional interests; the practise of officials and politicians leaking documents to the press to discredit opposing factions and officials was familiar and the Alemán administration recognized it as a growing problem. In early 1948, Alemán had even sought to introduce new restrictions that would make the publication of official documents an infringement of copyright. ${ }^{46}$ The idea that, under the PRI, the importance of access to government information was completely unknown'neither a theme in public debate which caught the attention of officials, nor a concern of

considerably...Furthermore, newspaper articles at various stages of his career add to the confusion by giving still other accounts of his activities'. MA to State Department, 2 August 1943, National Archives and Records Administration, Record Group 165, Military Intelligence Division Regional Files, Mexico (MIDRF), Box 2553. ${ }^{44}$ P. Piccato, 'Altibajos de la esfera pública en México, de la dictadura republicana a la democracia corporativa. La era de la prensa', in G. Leyva (ed.) Independencia y Revolución: Pasado, presente y futuro (Mexico City, 2010), 240-291.

45 B. Smith, The Mexican Press and Civil Society, 1940-1976: Stories from the Newsroom, Stories from the Street (Chapel Hill, NC 2018); V. Freije, 'Exposing Scandals, Guarding Secrets: Manuel Buendía, Columnismo, and the Unraveling of One-party Rule in Mexico, 1965-1984', The Americas 72, 3 (2015), 377-409. For a depiction of a weak, politically irrelevant press before the 1990s, see C. Lawson, Building the Forth Estate: Democratization and Media Opening in Mexico (Berkeley, CA 2002).

${ }^{46}$ Smith, Mexican Press, 89. 
the governed'- may help to dramatize recent progress towards transparency, but distorts the historical record. ${ }^{47}$ The Ruiz Cortines administration (1952-1958) began, as did many others, with promises to moralize public administration; this commitment was largely symbolic, but it made little sense to leave too many documentary hostages to fortune. ${ }^{48}$ At the same time, political and ideological changes help to explain why the demands of secrecy were met in different ways across the state apparatus. In the 1930s, ambitious policies of social reform, economic management and integration all drove data collection across a variety of state agencies. Agrarian reform in particular demanded 'herculean' feats of mapping and measuring; census-takers, teachers, government anthropologists, and trainee doctors were dispatched on gruelling rural odysseys to collect data useful for social control, national integration, and economic development. ${ }^{49}$ Redistributionist and nationalist policies also shaped how this data was categorized. After joining US-led efforts to standardize agricultural measurements in the 1920s, during the Great Depression Mexican statisticians developed their own heterodox measures of economic well-being and progress: official statistics counted foreign and nationally-owned industries separately, devised ways to measure and compare market and peasant production, and tried to distinguish between speculative and productive investment. ${ }^{50}$ As the dominant party moved rightward through

47 J. Peschard, Transparencia: promesas y desafíos (Mexico City, 2017), 167.

${ }^{48}$ S. M. Luna Elizarrarás, 'Enriquecimiento y legitimidad presidencial: Discusión sobre identidades masculinas durante la campaña moralizadora de Adolfo Ruiz Cortines', Historia Mexicana, 63, 3, 2014, 1377-1420.

49 Knight, 'The Weight', 216; Ervin, 'The 1930 Agrarian Census'; K. A. Rosemblatt, The Science and Politics of Race in Mexico and the United States, 1910-1950 (Chapel Hill, NC 2017), 135-168; G. Soto Laveaga, 'Seeing the Countryside Through Medical Eyes: Social Service Reports in the Making of a Sickly Nation', Endeavor, 37, 1 (2013), 29-38.

${ }^{50}$ A. Ribi Forclaz, 'Agriculture, American expertise, and the Quest for Global Data: Leon Estabrook and the First World Agricultural Census of 1930', Journal of Global History, 11, 1 (2016) 44-65; Niblo, War, 16-28. 
the 1940s, the government's interest in state-led social transformation waned and its interest in top-down political control waxed. Consequently, the government boosted intelligence services, and invested the political and financial resources to create permanent and secret archives. ${ }^{51}$ (The Ministry of Treasury, another federal agency key to the capital accumulation and foreign credit, also enjoyed a reputation for relatively bureaucratic functioning. ${ }^{52}$ ) Bureaucratic imperatives were far less pressing in other federal agencies though, and officials enjoyed great discretionary power over their records. Statistical categories also faithfully reflected (and helped legitimize) this ideological drift; during the Second World War, the more heterodox measurements of the 1930 s fell away as Mexico acceded to US demands to adopt its national accounting system. ${ }^{53}$

Given these changes, one possibility is that Flores destroyed the CMAEFA archive because it duplicated information held securely elsewhere. Both of Mexico's main political intelligence services - the Dirección Federal de Seguridad (DFS) and the Dirección General de Investigaciones Políticas y Sociales (DGIPS)- did send agents out to report on some of the biggest incidents of civil unrest over FMD; the DFS even arranged to plant a couple of spies within the commission, disguised as livestock appraisers. ${ }^{54}$ Still, there are some problems with interpreting the fire simply as the expression of a rational division of administrative

\footnotetext{
${ }^{51}$ Navarro, Political Intelligence; G. McCormick, The Logic of Compromise: How the Countryside was Key to the Emergence of Authoritarianism (Chapel Hill, 2016), 133-161. Mexico's national archive remains the responsibility of the Interior Ministry, evidence of the enduring official conception of an archive as 'something subordinate to the dictates of interior security'. Peschard, Transparencia, 47n40.

52 A. Knight, 'Corruption in Twentieth Century Mexico', in W. Little and E. Posada Carbó (eds.) Political Corruption in Europe and Latin America (New York, 1996), 219-236, 226; F. Valdés, 'La corrupción', 203.

53 Niblo, War, 16-20.

${ }^{54}$ A selection, almost certainly incomplete, can be found in: 'Campaña contra la fiebre aftosa', version pública, DFS/DGIPS, AGN, 2012; c.97 e.20, c.99 e.1, c.102 e.3, c.114 e.1., all in DGIPS, AGN.
} 
labour. The available intelligence documents suggest rather fragmentary reports, scattered over a few months in 1947 and again in late 1953, as one might expect of a still small and under-manned operation; the CMAEFA likely gathered more data on popular attitudes to FMD eradication and did so over the entire course of the campaign. ${ }^{55}$ In any case, as noted above, reports on popular unrest did not exhaust the potential fiscal, developmental or epidemiological value of the CMAEFA archive. (It was for these reasons that technical experts at the UN Food and Agriculture Organization, increasingly concerned with animal disease as a drag on rural development, urged national governments to retain village-level records of such campaigns. ${ }^{56}$ ) Moreover, as far as we know, the DFS was not generally in the habit of sharing its reports with other branches of the government, but guarded them as valuable political resources; given this, officials in other agencies would have had strong political incentives to keep similar records to hand. ${ }^{57}$

Flores's decision to destroy the CMAEFA archive was driven not its redundancy or duplication elsewhere, but rather a calculation of the political benefits and risks of keeping it- risks that only increased as the Alemán administration's term came to an end. The different types of corruption that structured the FMD campaign - and which could be

\footnotetext{
${ }^{55}$ For an account emphasizing the limited size and reliability of the DFS, at least before the 1960s, see S. Aguayo Quezada, La Charola. Una historia de los servicios de intelligencia en México (Mexico City, 2011). By contrast, Gladys McCormick argues that although the DFS 'lacked the resources to station agents through the country', it placed agents where most needed, used informants quite effectively, and generated a lot of paper reports: roughly one hundred each month on the Federación de Partidos del Pueblo Mexicano after its candidate lost the 1952 presidential election; over twenty-five thousand pages on the sugar industry and related peasant organizations between 1952 and 1965. McCormick, The Logic, $137,144,145$.

$56 \mathrm{See}$, for example, various reports in 'K. Kesteven, Branch chief, trip reports 1949-58', uncoded files, Animal Production Branch Files, Animal Production and Health Division, FAO archive, Rome.

57 Padilla and Walker, 'In the Archives'.
} 
directly traced to commission officials- were probably Flores' most immediate concern. The campaign provided abundant opportunities for 'government in the service of graft', and was plagued by accusations of peculation and extortion, particularly during the phase of slaughter. ${ }^{58}$ Indeed, the only official document mentioning the archive fire came in response to an enquiry by Fernando Morales Henestrosa, a rancher's son, who disputed one of the many fines imposed by the commission on non-cooperative livestock owners. ${ }^{59}$ In late 1947 , the government made an example of Senator General Felix Ireta Viveros after the grave into which thousands of his pigs had reportedly been buried- for which he had been handsomely compensated- turned out to be nearly empty: an affair the press bitterly dubbed 'the dance of the pigs'. ${ }^{60}$ Many other accusations of local and state officials involved in similar schemes show up in US field reports, Mexican complaints, and official memoirs. ${ }^{61}$ After briefly being forced out of the Senate to answer charges- an unprecedented sanction in postrevolutionary Mexico- in December 1951 Ireta re-entered the Senate and staged a rapid political comeback- that is, just prior to the archive burning. ${ }^{62}$ Indeed, as early as 1948 , the cartoonist for Mexico's influential daily Excélsior already foretold such an outcome. 'Freyre' likened the Ireta case to other contemporary scandals, although the cartoon is ambiguous on how a cover-up would happen: it remains unclear whether the archivists expect to fill the 'gap' in the files with the Ireta case, or whether the 'gap' represents a case-

\footnotetext{
58 Knight, 'Corruption', 227.

${ }^{59}$ Miguel Vargas Solórzano, Sec. Agricultura y Ganaderia, to Javier Diez de Urdanivia, Jefe de la Oficina Federal de Hacienda, 30 November 1966, AGN, SAG, Box 134, 'fiebre aftosa'. ${ }^{60}$ Machado, Industry, 71.

${ }^{61}$ Dozens of similar cases are reported in field reports, CEFMD, Operations, Box 29-30.

62 Various correspondence, DF, to Alemán, December 1951, AGN, 425.5/2-15A. On Ireta's camarilla in Michoacán and later career, see V. Oikión Solano, Michoacán en la vía de la unidad nacional, 1940-1944 (Mexico City, 1995); Rath, Myths, 103.
} 
file that has disappeared altogether. ${ }^{63}$ Such stories ensured that, decades later, vox populi remembered the CMAEFA as a 'bunch of cheats' (bola de fraudes). ${ }^{64}$

However, corruption also appeared in a more functional guise. While the campaign relied on information, it also relied very heavily on what Alan Knight dubs 'graft in the service of government': the use of murky discretionary procedures and outright bribes to implement policy and underpin political stability. ${ }^{65}$ The commission gathered data on market prices and offered rough guidelines to livestock appraisers, but it was understood that appraisers needed to exercise discretion in practise, inflating or deflating payments as they gauged the weight of public opinion and local opposition, the degree of virulence of the outbreak, and navigated the plethora of local standards of breeding. By the end of 1947, compensation prices diverged markedly in different states and, worried about public criticism these inconsistencies might provoke, the commission sought to rein in appraisers' discretion. In Jalisco, the commission even recruited representatives of livestock associations to work for a time as co-appraisers, whose distinctly generous appraisals greased the wheels of the campaign for several months; shortly afterwards, in the south of Veracruz the campaign refused to hire local cattlemen for the same role, and endured months of non-compliance, threats, and pot-shots. ${ }^{66}$ Corruption was multifaceted then: the archive fire shielded individual officials from accusations - or at least well-substantiated

\footnotetext{
63 The 'Richardi' and 'Honey' scandals concerned violent feuding within the avilacamachista clan from the state of Puebla- rivals of President Alemán. S. Niblo, Mexico in the 1940s: Modernity, Politics, and Corruption (Wilmington, DE 1999) 230-2, 287. 64 Interview with Andrés Héctor Quezada Lara by Myrna Parra-Mantilla, 2003, 'Interview no. 988,' Institute of Oral History, University of Texas at El Paso.

65 Knight, 'Corruption', 227. For more on varied and changing meaning of corruption in Mexico, see Lomnitz (ed.), Vicios públicos.

${ }^{66}$ Mulhern, Minatitlán, Veracruz, to Noyes, Mexico City, 10 February 1948, CEFMD, Operations, Box 29, Fields Reports, Veracruz.
} 
accusations - of profiteering and extortion; but it also protected the state's facade of coherence and formal consistency.

Similarly, Flores may also have been concerned that records indicating the full costs of disruption to different regions and social groups might fuel demands for a comprehensive government response to the hardships the campaign visited on peasant communities. In 1949, the Mexican government began to offer some sporadic credit, breeding stock and technical advice to help farmers devastated by the disease and slaughter. However, the evidence suggests that this 'repopulation' program was beset by political favouritism and focused on large commercial ranchers. ${ }^{67}$ In the summer of 1947, US and Mexican officials had pondered whether the campaign should move beyond individual indemnities, and provide an integrated program of rural credit, education and public works to help affected communities, but such a program never emerged. ${ }^{68}$

Freyre, 'In the archive: is this gap for the Ireta case?', Excélsior, 14 October 1947.

In the 1940s, old concerns with concealing corruption and new worries about the expansion of a reading public, were given further impetus by another factor: the need to manage

67 Figueroa, El tiro, 225-239.

68 Campaign in Mexico, 44. 
Mexico's increasingly close but tense relationship with the United States. For a start, functional corruption- or at least the informal and secretive allocation of resources- was not only a domestic matter. The arrangements channelling US funding were themselves rather dubious and demanded secrecy. The 'salvage' operation, whereby the USDA paid indemnities for cattle which Mexican officials then transported and sold to Mexico City's slaughter house, on the formal (but loosely enforced) understanding that profits would be reinvested in the FMD campaign, effectively worked as a discreet subsidy to the Mexican state to guarantee cooperation. ${ }^{69}$

At the same time, the Mexican government frequently deployed what John Dwyer has dubbed the 'diplomatic weapons of the weak' to blunt US insistence on objectionable policies (in this case, slaughter), extract resources, maintain political flexibility, and generally minimize costs, political and financial, to the Mexican state. ${ }^{70}$ In practise this meant Mexican officials obeyed bilateral agreements in principle, but dragged their feet on operations in politically sensitive regions. Over time, such everyday bureaucratic infighting was rather effective in reshaping US policy demands and commission organization; but it threatened to undermine the carefully cultivated image of Pan-American harmony and orderly bilateral negotiations between two coherent states. Moreover, Mexican officials were always wary of appearing to bend excessively to US demands. Tellingly, disputes in the commission often involved information and paper: at times the Mexican section omitted to provide information on infrastructure and troop levels, and repeatedly refused to put local

\footnotetext{
69 Unsigned report, c. July 1947, CEFMD, Reports, Box 1, 'Congressional Committee'. 70 J. J. Dwyer, 'Diplomatic Weapons of the Weak: Mexican Policymaking during the USMexican Agrarian Dispute, 1934-1941', Diplomatic History, 26, 3 (2002), 375-395.
} 
operational agreements in writing. ${ }^{71}$ One recurrent cause of tension was the initial diagnosis of disease outbreaks, since it crystallized very different understandings of risk. The early clinical symptoms of FMD among cattle were very hard to distinguish from relatively harmless cases of vesicular stomatitis. US veterinarians were instructed to assume the worst in all new outbreaks, and proceed to slaughter; Mexican veterinarians were more circumspect, preferring to recommend quarantine measures and wait until laboratory tests confirmed the presence of FMD. Again, these disputes produced numerous irate telegrams and phone records in the US archive, but Mexican veterinarians often preferred to keep discussions off-the-record. ${ }^{72}$ Such practises allowed for operational flexibility; they also reduced the risk of a paper trail indicating apparent subservience to the gringos without, as we will see, completely eliminating it.

US officials faced pressures of their own from inquisitive congressmen eager for proof that this complex and expensive campaign was working. In mid-1948, President Truman appointed General Harry Johnson, a retired cavalry officer and Texas oil executive, as the new US co-director of the CMAEFA to streamline the operation. ${ }^{73}$ Johnson was a renowned administrator and particularly skilled at generating the kind of easily digestible reports, maps and statistics that conveyed the intricacies of the campaign to sceptics in congress and the livestock industry. (So 'beautiful' were the maps that the commission public relations men began to create for the public, they elicited rueful comments from officials in the field: 'If they can eradicate the disease as well as they can draw a map, we

\footnotetext{
${ }^{71}$ White, Mexico City, to State Department (SD), July 9, 1953, Confidential US State Department Central Files, Mexico: Internal Affairs, 1950-54, Reel 27, 258.

72 For example, see exchanges between Noyes, Mexico City and Dicke, Tamaulipas, Dec. 1947-Jan. 1948, CMAEFA, Operations, Box 29, Radio logs.

73 'General Johnson Leaves Aftosa', April 1951, n.p., Sul Ross State University, Archive of the Big Bend, Aftosa Papers, Dr. Albert Heflin papers, N82-3B, aftosa scrapbook.
} 
should be home before long'.) ${ }^{74}$ In general, US politicians and officials were well aware that they had to find a way to reconcile the demands of eradication with local political realities -what State Department officials vaguely termed 'Mexican nationalism' - but exactly how this was to be achieved was unclear. ${ }^{75}$ Johnson - reputed to be 'the second toughest cavalry officer' after General George Patton- had his own ideas, and soon created an embarrassing problem for both governments. ${ }^{76}$

A dramatic plane crash and public scandal which rocked the commission for several weeks allows us to observe many of these problems in microcosm: internal conflicts over authority, money, and information; Mexican officials' struggles to maintain the image of a unified and sovereign state; and an inquisitive press. On 2 July 1948, a small commission plane crashed into the upper slopes of Citlaltépetl- the huge snow-capped volcanic peak bordering the states of Puebla and Veracruz- killing all 16 men on board. The plane's contents reflected the commission's joint organization. Eight US and eight Mexican veterinarians were on board, although US equipment and money predominated, including a metal briefcase containing a quarter of a million Mexican pesos. Unlike other suspicious air and automobile crashes in mid-century Mexico, the cause of the accident did not excite much comment; most assumed (and later investigations confirmed) that the pilot, despite his extensive experience, had unwisely strayed from the standard route, and been blown off

\footnotetext{
${ }^{74}$ Noyes, Mexico City, to Hess, Guadalajara, December 19, 1947, CMAEFA, Operations, Box 29, Radio logs.

${ }^{75}$ E. Iller, Assistant Secretary of State for Inter-American Affairs, to G. Elsey, Administrative Assistant to President Truman, 21 September 1950, Truman Library (TL), Heckler Papers, box 5, 'foot and mouth disease'.

${ }^{76} \mathrm{~F}$. E. Young, To the Regiment: The History of the 306th Cavalry Regiment and the 306th Armored Cavalry Group (Washington D.C., 1970), 72.
} 
course by a storm into a treacherous gulch shrouded in mist. ${ }^{77}$ Attention focused instead on the crash's aftermath and the commission's rescue and recovery operation. After a year in which the commission had carefully portrayed itself as the epitome of hemispheric cooperation, US ambassador Walter Thurston described how newspapermen literally screamed' about a violation of Mexican sovereignty, and subjected the Mexican public to 'a campaign of anti-Americanism that was most virulent'. ${ }^{78}$

The main cause of the scandal was a squad of armed US paratroopers, members of US Airforce mountain rescue, who parachuted onto the mountain to aid a chaotic rescue operation. There are conflicting accounts of the how the squad conducted themselves. Journalists portrayed them as gun-toting invaders who had violated Mexico's sovereignty and, along with US officials and Mexican lackeys, thrown their weight around and generally ordered Mexicans around in their own country. The paratroopers' own accounts portrayed themselves on the margins of a shambolic operation hamstrung by poor weather, mudslides, peasant villagers who refused to provide provisions and mules without payment, and bickering among CMAEFA officials. According to their log book, after the bodies had been brought down to the tiny mountain hamlet of La Ciénaga, wrapped in traditional woven bedrolls (petates), and laid out in the municipal hall, the operation remained ensconced in a fog of confusion and mistrust; the US section wished to descend as soon as possible with the decomposing bodies, while the Mexican section were wary of travelling after nightfall:

\footnotetext{
${ }^{77}$ Excélsior, 8 July 1948; El Universal, 8 July 1948. This verdict was later confirmed by the official findings of the Mexican Ministry of Communications and Public Works. Anderson DF, to Devauchan, Washington DC, 30 August 1948, CEFMD, File 34, Box 2, Reports. 78 Thurston to SD, 23 July 1948, Confidential US State Department Central Files, Mexico: Internal Affairs, 1944-48, microfilm (IAMSD), reel 6, 812.00/7-2348, 111.
} 
19:30. We go to bed. Our sleeping bags are under a shed. It's raining again and very cold.

19:45. There is a very loud argument going on in the rooms we are camped next to. One of the Doctors of the American section comes to us and asks for Col. Mondragon (sic.) as an interpreter. He also asks us to stand by for trouble. We are advised that there was 250,000 pesos on the plane which were recovered. A Mexican judge took charge of the money...After the money had been brought down the mountain...he tried to get Dr Anderson to count the money and be responsible for it. Dr Anderson refused and it seems they are trying to force it on him. The Dr supposes that the judge either personally has part of the money or is afraid to keep it. 20:00. Still an argument going on between members of the commission about the money. We don't know the score but are standing by.

23:30. The Americans and Mexicans are still at it. Mondragon has left them and gone to bed. There is much rain and fog. ${ }^{79}$

Other accounts suggest a rather more active role for the squad. One paratrooper admitted to firing several machine-gun rounds into the forest, but argued that these bullets had aided inter-American understanding: after a local policeman showed interest in the submachine gun he was carrying, he allowed the policeman to test it by firing into some trees. Apparently 'this gesture seemed to enhance the friendship between the Rescue team and

\footnotetext{
79 'Land Rescue Commander Log', 6 July 1948, in Colonel L. W. Proper, Directorate of Intelligence, USAF, to Paul Reveley, Division of Mexican Affairs, SD, 27 July 1948, IAMSD, reel 33, 812.7965/7-2748.
} 
the Mexican Constabulary'. ${ }^{80}$ Decades later Elmo Jones, a pistol-carrying US livestock inspector who General Johnson had ordered to the scene to secure the briefcase of pesos, provided a rather different account. As he and fellow inspector Lee Gates strode up the mountain trail, just as some Mexican soldiers were about to catch up with them 'about three-fourths of the way up the mountain', the paratroopers 'dropped right beside us. Thank the lord they were our Guardian angels from then on'. At the suggestion of Jones, the US captain sprayed a machine gun round into the surrounding treetops in order to show the Mexicans 'his firepower' ${ }^{81}$

These operational tensions were then compounded by the commission's attempts to censor press coverage of the crash. Upon reaching the wreckage, Dr Fred Anderson of the CMAEFA became concerned that the six photographers at the scene were obstructing the removal of the bodies with their demand for grisly photographs. He sent an 'Indian runner' down the mountain to the base camp at La Perla, with instructions to radio the CMAEFA headquarters in Mexico City and ask the US embassy to 'pressure' the press to prevent the publication of 'grotesque photos taken at the scene'. Shortly afterwards, the Mexican codirector, Flores, sent a radiogram from Mexico City to commission personnel on the mountain ordering all press cameras to be confiscated, receipts issued, and the images sent to General Johnson for review, citing concerns about decency and commission morale. ${ }^{82} \mathrm{~A}$

${ }^{80}$ C. Beal, 'Medical Report of Rescue Mission', Air Rescue Service, McDill Air Force Base, Tamp, Florida, 10 July 1948, in Colonel L. W. Proper, Directorate of Intelligence, USAF, to Paul Reveley, Division of Mexican Affairs, SD, 27 July 1948, IAMSD, reel 33, 812.7965/72748.

${ }^{81}$ Aftosa International Roundup (n.p., 1985), 48. Jones' story of the paratroopers dropping onto the mountain was also confirmed by a commission information officer. Interview with Samuel A. Montague, 30 October 1992, 21-2, TL, Oral History Interviews.

82 Mitchell, 'Diary of Search and Rescue', Engineering Division, to Noyes, Co-Director, Mexico City, 9 July 1948, CEFMD, Reports, Box 2, File 34. 
confused debate then ensued about how this order would be carried out. At La Ciénaga, the arrival of the runner from the peak had already 'triggered much shouting and confusion'. ${ }^{83}$ Members of the Mexican section initially assumed that US personnel would enforce Flores's order, but they quickly refused, claiming 'this was a matter for Mexicans' ${ }^{84}$ Mexican officials and soldiers then confronted photographers as they descended the mountain at La Perla, and a violent argument erupted. A couple of reporters handed over their cameras, but most refused. One taunted the Mexican soldiers for following gringo orders: 'Are you not ashamed to take orders from an American?' 85 (Further down the mountain, US officials now began to eject any newspapermen travelling in commission trucks, although they made an exception when the rainfall became too heavy, sowing further confusion. ${ }^{86}$ ) The standoff at La Perla eventually ended when commission officials and soldiers relented and allowed a handful of photographers to keep their cameras and films. ${ }^{87}$

The crash ignited a short-lived but notable scandal, and there followed ten days of intensive and notably unified press coverage. All of Mexico's national dailies covered the crash and journalists' allegations of US high-handedness and Mexican official servility. Tiempo magazine counted a total of 59 headlines, 3 editorials, 80 newspaper columns dedicated to the crash in only three days. ${ }^{88}$ Novedades complained about 'gringo orders' to

\footnotetext{
83 'Land Rescue Commander Log', 6 July 1948, in Colonel L. W. Proper, Directorate of Intelligence, USAF, to Paul Reveley, Division of Mexican Affairs, SD, 27 July 1948, IAMSD, reel 33, 812.7965/7-2748.

${ }^{84}$ Mitchell, 'Diary of Search and Rescue', Engineering Division, to Noyes, Co-Director, Mexico City, 9 July 1948, CEFMD, Reports, Box 2, File 34.

${ }^{85}$ Excélsior, 8 July 1948.

${ }^{86}$ Enoch, Field Engineer, 'Report of Activities Relative to Plane Crash', to Mitchell, Engineering Division, 9 July 1948, CEFMD, Reports, Box 2, File 34, 'Diary of Search and Rescue'.

${ }^{87}$ El Universal, 8 July 1948.

88 Tiempo, 23 July 1948.
} 
censor their reporters and refuse them rations and shelter; Mexican employees, rather than objecting to this treatment, 'looked for a tip, and attacked their own people in a most disgusting manner'.$^{89}$ Even Excélsior, which the US embassy noted was 'usually reliable' and pro-administration, reported a 'slap in the face to the good neighbor policy'. Its reporters described how US officials, particularly a Mr. Enoch - 'a type as low as the dirt'- treated them 'worse than animals'. Excélsior also singled-out Flores for supporting censorship; if this did not occur, it was only 'because perhaps the Americans had sense enough to think that they were not in their country and could not get away with that'.$^{90}$ El Universal even reported a final fracas as the bodies arrived in Mexico City; leather-jacketed US commissioner Richard Gottfried, a 'disgusting fellow', barred families from seeing the bodies, 'despotically addressed the families of the victims', and threatened to strike a reporter in front of the police.${ }^{91}$ Historical analogies were not lacking to hammer home the point: Ultima Hora condemned certain officials who permitted a 'punitive operation' in the 'heart of the Veracruz mountains', evoking the US cavalry's Punitive Expedition into northern Mexico in pursuit of Pancho Villa in 1916-17.92

US officials tended to blame 'yellow journalism' for the scandal -'irresponsible members of press' who sated the Mexican public's appetite for sensational, disgusting images. The images in the Mexican press were notoriously gruesome, but this interpretation badly misjudged the politics dynamics and role of the press. Reporters were well aware of the story's commercial potential; the group that arrived at the scene included some of the

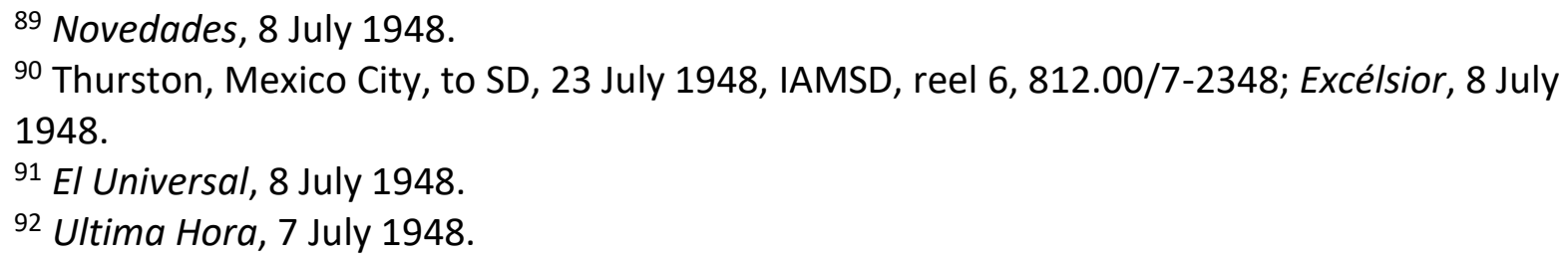
1948.

${ }^{91}$ El Universal, 8 July 1948.

92 Ultima Hora, 7 July 1948. 
most prominent reporters and photographers in the country, and their reports fully exploited the story's dramatic potential; they juxtaposed the horror of the crash with the natural beauty of the peak, and detailed their heroic ascent in the face of official harassment, altitude sickness, and the harsh climate. Journalists also defended their democratic right to report. The two main associations of journalists promptly delivered formal complaints to President Alemán calling on him to defend press freedom. ${ }^{93}$

These dry, principled objections only hinted at crime reportage's role as a form of unacknowledged political discourse, which historians increasingly recognize. From the $1920 \mathrm{~s}$ to the 1940 s, as public discussion was becoming increasingly restricted elsewhere, detailed reports and images of violent crimes in the police news served as one of the few forums for public debate about politics, justice and state performance. ${ }^{94}$ Indeed, reports from the crash echoed the visual grammar of the nota roja. They provided tragic, gruesome detail, but also forensic clues about the real nature of the event and possible holes in the official story. EI Universal was typical: twelve bodies in the plane, 'horribly incinerated beyond recognition', showed how the fuselage had exploded and burned immediately on impact. Indicating 'the intensity of the crash', which had thrown the passengers from the front of the plane across the mountainside, were bodies 'whose bones were entirely out of place, their faces almost completely destroyed'; curiously, 'the fully clothed body of a man was found under the left wing of the plane. He wore a brown expensive suit- slightly bald, thin. His cane was ironically placed, as if on purpose, on the wing of the plane'. 95

93 Thurston, Mexico City, to SD, 23 July 1948, IAMSD, reel 6, 812.00/7-2348.

94 P. Piccato, 'Murders of the Nota Roja: Truth and Justice in Mexican Crime News', Past and Present 223, 1 (2014), 195-231.

${ }^{95}$ El Universal, 8 July 1948. 
The fire of controversy was also fanned by a highly-charged political context. The summer of 1948 found President Miguel Alemán politically vulnerable, his supposedly 'imperial presidency' challenged by many forces. ${ }^{96}$ Newspapers exposed corruption within his inner circle, and his connections with blood-soaked Veracruz pistoleros; the FBN publicly accused Mexican officials of running the drug trade; left-wing students and labor organizations condemned the government's drift rightwards, while political and military factions within the revolutionary family all pushed against party control; two groups of generals hatched plans for a coup; in August there were even rumors that some would-be plotters machine-gunned Alemán's motorcade. ${ }^{97}$ Many groups seized on the crash on the volcano to criticize the government's servile attitude to the United States. One right-wing newspaper in Guadalajara even compared Alemán unfavorably with leftist ex-President Lázaro Cárdenas who, for all his faults, had at least refused to allow armed US soldiers to enter Mexico during the Second World War. ${ }^{98}$ Left-wing students gathered in downtown Mexico City to stone the US embassy, condemn mounting 'US imperialism', and demand that Mexico refuse to sign new hemispheric mutual-defense agreements being pushed by Washington. ${ }^{99}$

While newspapers portrayed the scandal as a clash between Mexican sovereignty and US power (and Mexican lackeys), this obscures some subtler intragovernmental

\footnotetext{
${ }^{96}$ E. Krauze, La presidencia imperial (Mexico City, 1997), 11-33.

97 On opposition, see: Thurston, Mexico City, to SD, July 23, 1948, IAMSD, reel 6, 812.00/72348; Rath, Myths, 93-103.

${ }^{98}$ El Occidental, 12 July 1948, reproduced in IAMSD, reel 33. On Cárdenas's earlier opposition to the presence of US military personnel while Secretary of Defense, see M. E. Paz Salinas, Strategy, Security, and Spies: Mexico and the US as Allies in World War II (University Park, PA, 1997) 107-8.

${ }^{99}$ F. Fagoaga et al., Mexico City, to Dirección General de Investigaciones Políticas y Sociales, 10 July 1948, AGN, Dirección General de Investigaciones Políticas y Sociales, 2-1/261/80.
} 
tensions, particularly between civilian and military agencies. The armed US rescue squad was only on the mountainside because on 3 July General Johnson had requested or accepted assistance from the USAF who had heard reports of the crash. In doing so, Johnson ignored the fine print of the relevant 1946 agreement by the Joint US-Mexico Defense Commission, a body created in 1942 to oversee military cooperation during the Second World War- a diplomatic blunder which infuriated the US ambassador and State Department. ${ }^{100}$ Mexican civil-military relations were also tense during the rescue, as they often had been during the campaign as a whole. Realizing Johnson's blunder, the US consul at Veracruz desperately tried to obtain retroactive permission for the paratroopers from Veracruz's military Zone Commander-General Alejandro Mange, among the most powerful of a still highly independent officer corp. Although the consul claimed he obtained (through an interpreter) Mange's authorization for the presence of armed US forces, Mange then denied having authorized anything, and later Mexico's Ministry of National Defense denied all knowledge of Mange's meeting and actions. ${ }^{101}$

Still, by mid-July, the US and Mexican governments had taken measures to ensure that 'the incident was closed'. ${ }^{102}$ After the street protests, the national press began to back away from the story, noting that investigations were under way, and that under no circumstances should Communist demagogues be allowed to take advantage of the dispute.

100 Daniels, SD, to Undersecretary, SD, 5 August 1948, IAMSD, reel 33, 812.7965/7-2748. On the role of the defence commission, see Paz, Strategy.

101 While the US consul assumed that he had obtained Mange's approval, a report filed later by the paratroopers confirmed Mange's version. Operation commander log, Colonel L. W. Proper, Directorate of Intelligence, USAF, to Paul Reveley, Division of Mexican Affairs, SD, 27 July 1948, IAMSD, reel 33, 812.7965/7-2748. On Mange's political autonomy, see P. Gillingham, 'Military Caciquismo in the PRlísta State: General Mange's Command in Veracruz', in B. Fallaw and T. Rugeley, Forced Marches: Soldiers and Military Caciques in Modern Mexico (Tucson, AZ, 2012), 210-237.

102 Thurston to SD, 23 July 1948, IAMSD, reel 6, 812.00/7-2348, 111. 
US Ambassador Thurston concocted an exchange of diplomatic notes to defuse the affair and pre-empt the need for an official apology. ${ }^{103}$ On 10 July, Mexico's Ministries of the Interior, Defense, and Agriculture all published reports vaguely exonerating the commission and Mexican authorities: US assistance was humanitarian in motive, no threat to sovereignty, and any errors or disputes were simply due to a 'hurried' atmosphere after the crash. ${ }^{104}$

The commission quietly removed a couple of employees from their posts, revamped its public relations, mended fences with the press, and moved public discussion to more edifying themes. In early August, a large public ceremony in the national stadium encapsulated this shift, both in its organization and content. It was co-organized by the Mexican section of the CMAEFA and La Prensa- the most popular and independent of Mexico's national dailies - which enjoyed rights to coverage. Throughout 1947, the national press, and particularly La Prensa, had published very critical reports on the slaughter campaign. In April 1947, some newspapermen even wrote to Alemán to suggest that the government pay them a direct subsidy to help publicize the campaign; Alemán rejected the offer, arguing that this was unnecessary since the CMAEFA employed their own press officers. The ceremony in the national stadium inaugurated a new level of cooperation between the Alemán administration and La Prensa, and the CMAEFA and the press in general, mediated by the Mexican section. ${ }^{105}$

Searching for a positive way to portray the story, the Mexican section settled on a reliable subplot in the drama of revolutionary nationalism: indigenismo, the official

\footnotetext{
103 Thurston, Mexico City, to SD, 13 July 1948, IAMSD, Reel 33, 812.7996/7-1348.

${ }^{104}$ Excélsior, 13 July 1948.

105 La Prensa, August 5, 1948; Various correspondence, April 1947, AGN, Ramo Presidentes, Miguel Alemán Valdés, 4255/2-34.
} 
valorization of putatively indigenous cultures. ${ }^{106}$ Several early press stories had mentioned the role of indigenous reservists and their families. For reporters, indigenous people were an important part of their adventure as city-dwellers encountering rural Mexico; reporters relied on them as mountain guides, listened to their remedies for altitude sickness- chewing garlic- and described their stoical demeanour, 'typical' of Totonac 'Indians'. ${ }^{107}$ (Absent were the villagers who effectively went on strike until they and their mules were fed properly.) The celebration in the stadium now made one General Lozada and his battalion of indigenous reservists the main protagonists of the story. By acting as guides, guarding the plane, and preventing robbery, they had demonstrated characteristic indigenous virtues of stoicism, 'discipline, 'abnegation', and an uncomplicated patriotism in which all Mexicans could take pride. ${ }^{108}$ Lozada and four thousand indigenous reservists and their families marched to the stadium, where they received plaudits from Mexican cabinet ministers, including the Secretaries of the Interior and of National Defense. They were given ploughs and a certificate dedicated to the 'humble heroes of Citlaltépetl' from a Mexico City-based indigenista club called the Unión Azteca Gran Luz. They were then treated to a display of drills and athletics by the city's army garrisons and transport police. At one point, militiamen also received flowers from a group of 'beautiful single young ladies'- secretaries employed by the CMAEFA- with whom they posed for photographs. ${ }^{109}$ This was a rather patronising, conservative, contradictory variant of indigenismo, typical of PRlísta Mexico, and well-suited

\footnotetext{
${ }^{106}$ On competing tendencies within indigenismo, and the consolidation of a conservative, assimilationist, and developmental approach by the 1940s see: A. Dawson, Indian and Nation in Revolutionary Mexico (Tucson, 2004) 157-9; R. López, Crafting Mexico: Intellectuals, Artisans, and the State After the Revolution (Durham, 2010), 6-11. 106 Rath, Myths of Demilitarization, 31-53

107 El Universal, July 8, 1948.

108 La Prensa, August 5, 1948.

109 Ibid.
} 
to the occasion. There was no mention of the reserve militia's troublesome associations with radical agrarianism, so controversial in the 1930s; Lozada appeared simply as a bulwark of discipline and order. ${ }^{110}$ La Prensa simultaneously celebrated the apolitical professionalism of army officers, even as it lavished praise on Lozada, both a reserve commander and 'patriarch of the sierra negra' who oversaw the region's development and whose orders indigenous people followed 'blindly'. ${ }^{111}$

As important was the absence of US actors in any of this. Discussing the planning of the event with his Mexican counterpart, General Johnson noted that newspaper coverage and public opinion had made US participation in such events 'untenable'. He left the organization up to the Mexican section, but made several suggestions. US officials would now seek to contribute to all such events 'quietly and unostentatiously'; although the US Section contributed money and equipment, and some gifts to the reservists to 'show our gratitude', no US officials were invited, no seats were set aside for US citizens, and any US citizens who attended would do so only as individuals alongside 'their Mexican friends'; the Mexican press ought not to mention the use of US equipment and money. Johnson left the use of a US flag to Flores's 'good judgment and exquisite taste'; Flores declined to include one. ${ }^{112}$

Privately, officials also covered up their tracks and protected themselves, carefully removing documentary evidence that might link them to the scandal. General Johnson's final report to the USDA obfuscated the origins of orders to deploy the paratroopers, was silent on the question of censorship, and instead offered vague reassurances that the

\footnotetext{
110 Rath, Myths of Demilitarization, 31-53.

111 La Prensa, 8 July, and August 5, 1948

112 Johnson to Flores, August 6 1948, File 34, Box 2, Reports, RBAI, CEFMD, RG17, NARA.
} 
scandal would not make the Truman administration politically vulnerable. ${ }^{113}$ Flores's efforts focused on removing evidence from the radio logs. Ironically, regular radio logs had been introduced in the CMAEFA in late 1947 by USDA officials wary of radio technology's paradoxical effects; radio communications hugely accelerated communications and action, but sapped the commission's capacity to record and archive its everyday activities, including the kind of ad hoc operational agreements upon which it relied. In the days following the scandal, Flores's order to confiscate cameras and subject press reports to US censorship disappeared from all but one of the commission's radio logs. A US radio engineer, one of dozens who witnessed the original order, noted sagely: 'This is hard to understand. I can only conclude that the logs have been tampered with'. ${ }^{114}$ Years before the archive fire, Flores had already learned of the political dangers posed by the paper accumulating in CMAEFA offices.

In his eagerness to avoid the taint of US servility, and awareness of the press's residual power to embarrass and discredit clumsy officials, Flores was very much a político of his time. The political risks of cooperating with US agencies in mid-century Mexico should not be exaggerated; Mexicans' appetite for anti-American posturing was never allconsuming or inexhaustible; indeed, to talk of blanket Mexican 'anti-Americanism', as some US officials tended to do, is misleading, implying a fixed and uniform attitude which arguably did not exist, and helps reify national differences and obscure the many similarities between the two societies. ${ }^{115}$ Insinuations of yakeephilia were not necessarily politically

\footnotetext{
113 Johnson, Mexico City, to Secretary of Agriculture, 15 July 1948, CEFMD, Reports, Box 2, File 34.

114 Mitchell, 'Diary of Search and Rescue', Engineering Division, to Noyes, Co-Director, Mexico City, 9 July 1948, CEFMD, Reports, Box 2, File 34.

${ }^{115}$ For an unusually careful discussion of Mexican attitudes, see A. Knight, U.S.-Mexican Relations, 1910-1940: An Interpretation (San Diego, 1987).
} 
fatal: Ezequiel Padilla - married to an American- was accused of being too close to the US politically and personally and lost the 1945 presidential election, but it is questionable that this was his most important political obstacle; the PRI's Adolfo Ruiz Cortines won the tense 1952 presidential election, despite being accused of aiding the US invasion of Veracruz in 1914. ${ }^{116}$ Nevertheless, an official's relationship and public stance towards the United States formed a necessary part of their political calculus, and one that ambitious PRlístas - like Flores- were well aware required astute management. For our purposes, the crucial point is that this management shaped processes historical sociologists rightly consider at the very core of state-making - the gathering and archiving of information to govern a territory and its population, human and non-human.

\section{Conclusions}

It is hard to know exactly why Oscar Flores decided to burn Mexico's share of the CMAEFA's archive. This article has argued that this was no random personal quirk, but the result of shifts in the political context of 1940s Mexico, and an assessment of opportunities and risks posed by this particular archive. The argument that the CMAEFA records were technically useless is hard to credit, given the amount and nature of data obtained on rural society, its politics, topography, and germs- information the state generally valued in its efforts to govern and develop the countryside. Still, as the PRI turned rightwards, it prioritized the archives of political spies, while other federal agencies' approach to information-gathering and record-keeping was far more selective and contingent, an eloquent indicator of the

116 Navarro, Political, 121-149, 222. 
regime's concern with social control rather than radical transformation. Like earlier municipal and state-level figures, Flores was no doubt eager to eliminate evidence of incoherence and the different types of corruption that both sapped the campaign's budget and underpinned its ability to operate - and to do so before he was replaced in office by another (likely rival, possibly leak-prone) PRlísta. The need to maintain the appearance of orderly, coordinated bilateral relations and Mexican sovereignty reinforced these concerns. The story of the crash on Citlaltépetl illustrates the messier reality of shared sovereignty in the commission, beset by muddled-lines of authority between and within governments, mistrust, miscommunication, and struggles over money, information, and accountability. It also shows how Mexican officials were acutely aware of the political risks posed by a meddlesome press and increasing cooperation with US agencies well before the archive fire that ended the campaign, and had already destroyed administrative records to minimize them.

All governments gather and destroy information, but understanding how they do this can powerfully illuminate their workings. On close examination, the FMD campaign emerges as something like a dictablanda in miniature- technical and developmental rather than redistributionist, beset by internal conflicts, with a tenuous and contested grasp of rural societies and ecologies, and propelled by ad hoc solutions; hard-edged repression had a central role, but it did not and could not rely on force alone. While new histories of Mexico's Dirty War are vital in countering official amnesia and entrenched impunity, it is difficult to fit the story of the FMD campaign and its archive into a narrative of evergrowing, modernizing surveillance and repression. ${ }^{117}$ To understand the early PRI's political

117 Pensado and Ochoa, 'Introduction'. 
dynamics and - no small matter for historians- the documentary traces left (and not left) to us by this period, we need to trace how officials learned to juggle clientelism and bureaucracy, repression and mediation. The PRI boosted some kinds of informationgathering, but this impulse competed with, and was undercut by the simultaneous need to build political coalitions through patronage, ensure the circulation of political insiders and elites, and cooperate with US agencies while shielding the details of these practises from the press. To use Scott's visual metaphor, PRlístas extended the state's gaze into some areas, averted its eyes at times, and blinded it on occasion. In turn, this history can help us understand how Mexico entered its phase of neoliberal reform and ostensible stateshrinking in the 1980s with large spy archives, but- after decades of apparent developmentalist endeavour - no cadastral map, and many other federal agencies which were substantially opaque even to their own officials. ${ }^{118}$

The FMD campaign did not build a mighty, autonomous state by conventional sociological standards. But it did help to build something. Mexico's epizootic crisis, like other dramatic outbreaks of disease, produced a new veterinary infrastructure, albeit one whose founders covered up the political conditions of its own creation; the government still struggled to count livestock and map property, but it did acquire an effective surveillance system for animal disease- a kind of early-warning system for microbes. Most important, the campaign severely tested and honed Mexican officials' ability to project an image of territorial sovereignty, coherence, and consistency- to affect the 'mysterious effect of the state as a separate, self-willed entity' distinct from society and from other states. ${ }^{119}$ This

\footnotetext{
${ }^{118}$ Craib, Fugitive Landscapes, 255; Schwegler, 'Reading the Illegible State'.

119 T. Mitchell, 'The Limits of the State: Beyond Statist Approaches and Their Critics', American Political Science Review, 85, 1, (1991), 77-96, 86.
} 
relied on press management and new propaganda techniques, and the simultaneous building, protecting, and destruction of different kinds of archives; these practises hardly eliminated critical voices, but they could deny those voices the precision and amplifying power of written documents. At the least, the FMD crisis does seem to have taught some enduring lessons to those involved. In subsequent years, Oscar Flores rose through Mexico's political system; he served as governor of his home state of Chihuahua (1968-74), headed the Attorney General's Office (1976-1982) as it systematically disappeared and tortured political and guerrilla opponents, and collaborated with the US Drug Enforcement Agency on the so-called Operation Condor: another militarized bilateral taskforce dispatched into Mexico's hostile and opaque countryside, in pursuit of marijuana and opium traffickers. Naturally, when Flores sought to reassure US officials planning Condor, he pointed to his earlier role in the CMAEFA 'where he accumulated considerable experience in working with Americans and Mexican military on operational matters'- and in which he had done so much to collect and destroy information, and balance the political demands of legibility and deniability. ${ }^{120}$ To date, the archive of the Condor commission is yet to materialize.

120 'First meeting on narcotics with new attorney general', US embassy, Mexico City, to State Department, December 8, 1976, Special Assistant to the President-Bourne, 'Mexican and US Cooperation in Narcotics Control, 12/76-1/77 [CF, O/A 156] [1]', Box 40, Carter Library. I am grateful to Benjamin Smith for providing a copy of this document. 
